\title{
IMPACT OF DERIVATIVE USAGE ON FIRM'S RISK AND VALUE: A COMPARATIVE ANALYSIS OF PAKISTAN AND MALAYSIA
}

This study empirically examines the effect of derivative usage on firm's risk and value by employing sample data of Pakistani and Malaysian listed companies for the period of 2004-2010. Supporting the risk management use of derivative instruments, the study finds that the usage of derivative instruments significantly minimizes firm's risk, with respect to operating cash flow variability in both Pakistan and Malaysia, although the extent of risk reduction is higher in Malaysian firms. While considering variability in earning per share as a firm's risk, the findings imply that Pakistani firm's earning per share variability is irrelevant for firm's derivative usage, whereas Malaysian firms are able to minimize such volatility by using derivative instruments. The results show the insignificant effect regarding the relationship of derivative usage with firm's value of Malaysian corporations, indicating that as Malaysia has developed capital market and firms are more geographically diversified in comparison to Pakistan, thus their value relevance of derivative usage are limited. While in the case of Pakistan, the use of derivative instruments significantly enhances firm's value. Pakistan

Keywords: foreign currency derivatives, interest rate derivatives, firm value, firm risk,

DOI: $10.15611 /$ aoe.2017.1.08

\section{INTRODUCTION}

The Asian Financial Crises of 1997/98 and the US global financial crunch of 2008 have highlighted the significance of using derivatives to hedge the adverse effects of exchange rate and interest rates on firm's risk and value (Rafiq et al. 2012; Paligorova and Staskow, 2014). Despite the great concern of regulators and policy makers about the losses which occurred due to derivative usage (i.e. speculation), non-financial firms are using derivatives for managing firm's risk. The growing use of derivatives as a risk management instrument over recent decades, has shifted the attention of practitioners and academics from theory to practice and led to answering such questions as the determinants of derivative usage and the influence of such usage on firm's risk and value. Regardless of the derivative disclosure requirement of International Accounting Standards (IAS) in 1999, the

\footnotetext{
* COMSATS Institute of Information Technology, Lahore, Pakistan

** Government Sadiq College Women University Bahalwalpur, Pakistan
} 
literature depicts both manipulative and risk managing roles of derivatives as empirical evidence regarding the impact of derivative usage on firm's risk and value is still mixed.

Fabin (2010) stated that Senator Judd Gregg while arguing on financial regulatory reform defined derivatives as a huge complex issue. As, on the one hand, considering the market imperfections pointed out by Smith and Stulz (1985), derivative usage for hedging firm's exchange rate (ER) and the interest rate (IR) risk reduce firm's risk and maximizes firm's value. While on the other hand, according to Black and Scholes (1973), corporations use derivative instruments for risk taking, in cases when firm's value for equity holders matches the payoff pattern of the out-of the money option, then managers are more likely to increase the risk of the firm in order to maximize the value of their option, resulting in a negative firm's value. In addition, Jensen and Meckling (1976) stated that highly a levered firm has an incentive to shift its funds from bondholders to equity holders by undertaking highly risky projects, which puts an upward and downward pressure on firm's risk and value respectively. Furthermore, adverse changes in ER and IR enhance the inherent risk as a corporation which is already in a hedging position faces huge losses by the unpredictable ER and IR movements leading to a decrease in firm's value. Managers have also an opportunity to use derivative instruments in their own interest as they have day to day information regarding derivative trading, which increases their chances to capitalize favorable ER and IR movements, resulting in an increase in firm's risk and a decrease in firm's value. Hence the net effect of derivative usage on firm's risk and value is still an empirical question.

Academic researchers have tested the role of derivatives as a risk management instrument by examining the effect of derivative usage on firm's risk and value, although literature is mostly concentrated in countries having a developed derivative market (Nguyen and Faff, 2010 (a\&b); Fauver and Naranjo, 2010). However, to the best of the author's knowledge, no study has comparatively analyzed the risk management role of derivative usage, except Bartram et al. (2011), which analyzes 6,999 non-financial firms from 50 countries for the period of 2001-2002 and finds that firms are using derivatives for minimizing firm's risk and maximizing firm value. The present paper, therefore, contributes to the existing literature by comparatively analyzing the effect of derivative usage on firm's risk and value of countries having a developing derivative market. The study gathers derivative usage data of 165 Pakistani and 266 Malaysian non-financial firms listed on the Karachi and Bursa stock exchanges respectively for the 
period 2004-2010. The selection of sample countries is backed by a few justifications. Firstly, both countries obtained independence from British rule in the same economic arena and faced almost similar cultural values and norms (Kadir, 2003). Secondly, they both have developing derivative markets and use over-the-counter derivative instruments for risk management purposes (Wyman, 2013). Thirdly, they have the same accounting standards which reduce the biases results. Lastly, despite all the above similarities, currently Malaysia is comparatively more developed and has a higher involvement in international trade activities (Paracha, Manzoor, 2015) and also has a comparatively developed derivative market (Hohensee, Lee, 2006). Hence the study expects that the value relevance and risk reduction effects of derivative usage are higher in Malaysian firms in contrast to Pakistani.

The remaining part of the paper is arranged as follows: Section 2 documents the relevant empirical literature regarding the derivative usage and its subsequent effect on firm's risk and value. Section 3 discusses sample data, variables and empirical models, while Section 4 reports and discusses the results about the determinants of derivative usage and its resulting influence on firm's risk and value. Section 5 concludes the study and gives some policy implications.

\section{LITERATURE REVIEW}

Traced back to Modigilani and Miller (1958), in the case of the perfect capital market, risk management does not affect a firm's investment and financing policies as investors are able to manage risk at their end. Financial theorists claim that under certain market imperfections, firms have an opportunity to increase shareholder's wealth by reducing firm's risk by employing derivative instruments. (Smith, Stulz, 1985; Stulz, 1984; Froot et al, 1993; Myers, 1977). By using various sample data of both developed and emerging economies, the present literature finds that the corporate use of derivative instruments enables corporations in decreasing cash flow variability by hedging financial distress cost, agency costs, exchange rate exposure (Horng, Wei, 1999; Haushalter, 2000; Nguyen, Faff, 2002; ElMersy, 2006; Hu, Wang, 2005; Hsu et al., 2009; Ameer, 2010; Afza, Alam, 2011(a, b \& c)).

The empirical literature supports the theoretical predictions by Smith and Stulz (1985), Stulz (1984), and Reynolds et al. (2007), empirically find that corporations are using derivatives in order to reduce the variability in cash 
flows for investment, similar as in Froot et al. (1993). Similar findings are identified by Davies et al. (2010), that firms having higher under-investment problem are more likely to use derivatives for hedging. Nguyen (2011) also shows that firms having higher financial constraints are more likely to use derivatives for risk management purpose. Financial distress costs are found to be a significant determinant of a firm's derivative usage (Nguyen, Faff, 2003), both foreign currency derivatives (FCD) and interest rate derivatives (IRD), consistent with the theoretical justification of Smith and Stulz (1985). Similar findings are reported by Borokhovich et al. (2004), that firms having high leverage are using derivative instruments to avoid financial distress costs, which also tally with Clark et al. (2006) and Graham and Rogers (2002). However, Davies et al. (2010) show no significant relationship between derivative usage and a firm's financial distress costs. Supporting economies of scale, Muller and Verschoor (2007), find that large sized firms are using more derivative instruments, which is also consistent with Junior (2007) and Fazillah et al. (2008). By using sample data of Latin American countries, Schiozer and Saito (2009) depict the significant positive effect of growth opportunities, size and tax convexity on a firm's derivative usage, in line with Smith and Stulz (1985). Singh and Upneja (2008), and Clark et al. (2006) identify that firms with higher financial distress, liquidity constraints and foreign exchange exposure are tending more towards derivative usage, also similar to Junior (2007). Tufano (1996), by examining the gold mining industries, demonstrates a manager's compensation level as a significant determinant of a firm's derivative usage, supported by Stulz (1984). Concluding the above discussion, theoretical literature finds mixed evidence in favor of both manipulation and risk management usages of derivative instruments.

Empirical studies have directly tested the relationship between the corporate use of derivative instruments and firm's risk by employing different sample data. Most studies have explored the effect of derivative usage on firm's risk in countries having a developed derivative market, like Hentschel and Kothari (2001), who by considering sample data of 929 firms, report on significant positive and negative impact of derivative usage of nonfinancial and financial corporations on firm's volatility in equity return respectively. By using sample data of 326 firms, Chiang and Lin (2007) show the significant negative impact of derivative usage on a firm's ER exposure, whereas a firm's operational hedging technique is found to be unrelated to the firm's ER exposure, similar results are shown by Gay et al. (2011) and Jorge and Augusto (2011). By matching users and non-users on 
the basis of propensity to hedge, Bartram et al. (2011) examine the 6,888 non-financial firms and report the significant negative impact of financial derivatives on a firm's total risk and systematic risk. Nguyen and Faff (2010a), by employing sample data of 469 firms, depict the insignificant negative impact of FCD and IRD usage on firm's risk, excluding FCD instruments which demonstrate the significant negative impact on firm's systematic risk. Aysun and Guldi (2011), by employing sample data of emerging countries, identify derivative market participation as a decreasing function of ER exposure of firms.

Risk management literature also examines the relationship of derivative usage with firm's value. Similar to the previous one, most of the studies were done in countries having a developed derivative market, however the results are inconclusive in nature. mpirical evidence on the value increasing effects of derivative usage mostly covers U.S. For instance, Allayannis and Weston (2001) observe 4,320 firms and identify that the usage of FCD can enhance firm's value, almost $4.8 \%$ to $5.2 \%$, for firm's with foreign sales. While in the case of firms having no foreign sales, the usage of FCDs illustrates the insignificant positive effect on firm value. Graham and Rogers (2002) study 442 non-financial firms and determine that the tax benefits attained from derivative usage put an upward pressure on firm's value by $1.1 \%$; similar findings are observed by Carter et al. (2006), that hedging provides a value premium of $10 \%$. Like them, few studies use sample data other than that of U.S. non-financial firms and depict the significant positive effect of derivative usage on firm's value (Hagelin, 2003; Pramborg, 2004; Dan, Gu, Xu 2005; Kapitsinas, 2008; Faseruk, Mishra, 2008; Clark, Mafteh, 2010).

Some studies find an insignificant relationship between derivative usage and firm value, for example, Jin and Jorian (2006), by analyzing 119 U.S. oil and gas companies, conclude that hedging fails to give any value premium, to corporations which might be due to the specific industry type. Similarly, Naito and Laux (2011), by using sample data of 434 U.S. firms, depict the insignificant effect of derivative usage, designated for hedging, on firm's value. Khediri (2010), by using sample data of 250 French non-financial firms, depicts the insignificant negative and positive impact of FCD and IRD usage on firm's value respectively, which is consistent with Lookman (2004) and Fauver and Naranjo (2010). By taking sample data of 468 firms/year values of Australian non-financial firms, Nguyen and Faff (2010b) identify that usage of hedging instruments and the extent of such hedging reduces firm's value. A small number of researchers have tested the relationship 
between derivative usage and firm value by using sample data of countries having a developing derivative market, like Gomez et al. (2009), examined eight Colombian non-financial firms and showed the significant positive impact of derivative usage on firm's value. By using 40 Malaysian firms, Ameer (2009) found the significant positive effects of derivative usage on firm value, measured by the market price.

The existing literature, comprising mostly of developed countries, shows mixed evidence regarding the determinants of derivative usage and whether such usage adds value or reduces firm's risk. Whereas none has comparatively examined the role of derivatives as a risk management instrument in Asian countries with a developing derivative market. Therefore the current study contributes to the existing literature by comparatively analyzing the effect of derivative usage on firm's risk and the value of gathering sample data of 165 Pakistani and 266 Malaysian nonfinancial firms. In addition, the existing literature uses market risk variables while the present study considers the variability in operating cash flows and earnings per share for measuring firm's risk, supported by Allayannis et al. (2006). A significant positive (negative) relationship between firm's risk (value) and derivative usage reflects the manipulative or speculative employment of derivative instruments, while a negative (positive) relationship of a firm's risk (value) shows the usage of derivative instruments for risk management purposes. The study expects to help decision makers in comparatively analyzing the role of derivative instruments in influencing firm's risk and value in countries having a developed derivative market.

\section{METHODOLOGY}

The objective of the study is to comparatively analyze the effect of firm's specific factors on derivative usage and the influence of derivative usage on firm's risk and value of Pakistan and Malaysian non-financial firms listed on their respective stock exchanges for the period of 2004-2010. Firms which remain listed on the stock exchange for the whole period and neither merge nor are acquired by other firms are considered as part of the sample. In addition, financial firms are excluded from the sample as they are both users and traders of derivative instruments, and thus result in biased findings. The final sample is composed of 165 Pakistani and 266 Malaysian non-financial firms listed on their respective stock exchanges. According to the International Accounting Standards, it is compulsory for non-financial firms 
to disclose their information regarding usage of derivatives as risk management instruments.

Based on the existing literature, the study expects that the use of derivatives under certain market imperfections may increase firm's value and decrease firm risk. Firms with higher debt financial distress costs, size, underinvestment problem, liquidity constraints, tax convexity, managerial ownership and exchange rate exposure are more likely to use derivatives for hedging, which in turn minimizes their risk and maximizes firm's value. Therefore significant negative and positive relationship is hypothesized regarding the relationship of derivative usage with firm's risk and value. However, in order to better understand the effect of derivative usage on firm's risk and value, the study first estimates the determinants of derivative usage. Following the existing literature, the logit model is used for examining the determinants of the firm's decision to use derivative as the dependent variable that equals ' 1 ' if the firm declares its use of derivatives, and ' 0 ' otherwise.

$$
\begin{aligned}
D E R I V_{i t}= & \alpha+\beta_{1} D E B T_{i t}+\beta_{2} F D C_{i t}+\beta_{3} I N C_{i t}+\beta_{4} S_{I Z E_{i t}}+ \\
& \beta_{5} M K B K_{i t}+\beta_{6} A G C F_{i t}+\beta_{7} R O A_{i t}+\beta_{8} L I Q_{i t}+\beta_{9} D P_{i t}+ \\
& \beta_{10} T A X_{i t}+\beta_{11} M N G R L_{i t}+\beta_{12} F S_{i t}+\beta_{13} D V R S F_{i t}+\varepsilon_{i t}
\end{aligned}
$$

The description of the variables and others subsequently used in the empirical analysis are presented in Table 1.

Second, the study examines the influence of derivative usage on firm's risk. In contrast to risk management literature, the present study employs volatility in operating cash flows and earnings per share as a dependent variable, as market risk measures do not explain the stability of the firm's financial statements and are not directly related to firm's risk management policies (Allayannis et al., 2006). Our study therefore, based on the current literature, empirically examines the role of corporate derivatives in minimizing firm's risk, along with the other firm specific factors that are identified as significant determinants of a firm's risk by using the OLS. The standard errors are grouped by year and firm as specified below.

$$
\begin{aligned}
F R_{i t}= & \alpha+\beta_{1} D E R I V_{i t}+\beta_{2} D E B T_{i t}+\beta_{3} F D C_{i t}+ \\
& \beta_{4} S_{Z I} E_{i t}+\beta_{5} L I Q_{i t}+\beta_{6} T A X_{i t}+\beta_{7} M N G R L_{i t}+ \\
& \beta_{8} F S_{i t}+\beta_{9} D V R S F_{i t}+\varepsilon_{i t}
\end{aligned}
$$

Finally, backed by the existing literature, the study analyzes the effect of derivative usage on firm's value by estimating the model below, controlling 
for other firm-specific factors known to be the determinants of firm's value, while standard errors are clustered by year and firm.

$$
\begin{gathered}
F V_{i t}=\alpha+\beta_{1} D E R I V_{i t}+\beta_{2} D E B T_{i t}+\beta_{3} F D C_{i t}+\beta_{4} S I Z E_{i t}+\beta_{5} R O A_{i t}+ \\
\beta_{6} D P_{i t}+\beta_{7} T A X_{i t}+\beta_{8} M N G R L_{i t}+\beta_{9} F S_{i t}+\beta_{10} D V R S F_{i t}+\varepsilon_{i t}
\end{gathered}
$$

In addition, in order to examine whether the risk reduction effects and value relevance of derivative usage vary with the types of derivative instruments, the study re-examines the above models by classifying the sample data on the basis of types of derivative instruments, FCD and IRD.

Table 1

Model variables

\begin{tabular}{l|l}
\hline \multicolumn{1}{c|}{ Variable } & \multicolumn{1}{c}{ Definition } \\
\hline$D E R I V$ & Dummy variable with value '1' if the firm uses derivatives and '0' otherwise \\
\hline$F R$ & Variation in operating cash flow to sales and variability in earnings per share \\
\hline$F V$ & Tobin's Q \\
\hline$D E B T$ & Total debt to total assets \\
\hline$F D C$ & Tangible assets to total assets \\
\hline$I N C$ & Earnings before interest and taxes to interest expense \\
\hline$S I Z E$ & Log of total assets \\
\hline$M K B K$ & Market value of assets to book value of assets \\
\hline$R O A$ & Net income to total assets \\
\hline$D P$ & Current assets minus inventory to current liabilities \\
\hline$T A X$ & Dividends per share to earnings per share \\
\hline$M N G R L$ & Dummy variable with value '1' if the firm has tax losses and '0' otherwise \\
\hline$F S$ & Percentage of managerial ownership \\
\hline$D V R S F$ & Log of foreign sales \\
\hline
\end{tabular}

\section{EMPIRICAL FINDINGS}

Table 2 reports the descriptive statistics of all variables of Pakistani and Malaysian non-financial firms. Statistics show that Pakistani and Malaysian firms have a similar firm value, while Malaysian corporations have comparatively more unpredictability in operating cash flows and earnings per share. Regarding firm specific operating characteristics, Pakistani firms are found to have a higher debt ratio of almost $58 \%$ and lower tangible assets of $48 \%$. Corporations are large in size, with lower profitability and higher 
liquidity level. Firms are paying $26.4 \%$ of their earnings as a dividend, reflecting that corporations are paying dividends to convey a signal regarding their financial position. Managers have on average 52\% ownership in the firm's equity. 16\% of Pakistani firms are geographically diversified, reflecting the fact that fewer firms are involved in operational hedging technique.

In the case of Malaysia, firms have similar growth opportunities as Pakistani firms, although they have higher variability in operating cash flows and earnings per share. They are identified as small size, highly indebted firms and have high financial distress costs. Similarly to Pakistani firms, Malaysian firms also have lower profitability and higher liquidity, which enables them to pay more dividends. Although firms have managerial ownership of almost $11.94 \%$, which is much lower than Pakistani firms, however firms are more operationally hedged as $58 \%$ firms are geographically diversified.

Table 2

Descriptive Statistics

\begin{tabular}{l|c|c|c|c}
\hline \multirow{2}{*}{ Variable } & \multicolumn{2}{|c|}{ Pakistan } & \multicolumn{2}{c}{ Malaysia } \\
\cline { 2 - 5 } & Mean & Standard Deviation & Mean & Standard Deviation \\
\hline$F V$ & 1.464 & 2.5559 & 1.46 & 4.71 \\
\hline$F R 1$ & 0.019 & 0.025 & 13.745 & 0.6761 \\
\hline$F R 2$ & 2.164 & 3.138 & 5.519 & 20.299 \\
\hline$D E B T$ & 0.582 & 0.213 & 0.412 & 0.255 \\
\hline$F D C$ & 0.481 & 0.219 & 0.328 & 0.260 \\
\hline$I N C$ & 9.00 & 18.362 & 20.890 & 41.438 \\
\hline$S I Z E$ & 6.501 & 0.653 & 5.561 & 0.544 \\
\hline$A F C F$ & 1.288 & 6.2501 & 1.377 & 13.527 \\
\hline$R O A$ & 0.045 & 0.3284 & 0.049 & 0.086 \\
\hline$L I Q$ & 1.441 & 1.0669 & 2.827 & 6.758 \\
\hline$D P$ & 0.264 & 0.5419 & 0.300 & 5.808 \\
\hline$T A X$ & 0.270 & 0.444 & 0.720 & 0.449 \\
\hline$M N G R L$ & 52.714 & 24.61 & 11.938 & 16.663 \\
\hline$F S$ & 2.983 & 2.8143 & 2.411 & 2.539 \\
\hline$D V R S F$ & 0.167 & 0.373 & 0.580 & 0.494 \\
\hline
\end{tabular}

Note: $F R_{l}$ depicts variability in operating cash flows and $\mathrm{FR}_{2}$ is measured by variability in earnings per share.

Source: authors' own 
Table 3

Summary Statistics by Derivative Usage

\begin{tabular}{l|c|c|c}
\hline \multicolumn{4}{|c}{ Panel A: Pakistani Firms } \\
\hline \multicolumn{1}{c|}{ Variable } & Users (750) & Non-Users (399) & Tests for Differences \\
\hline$F R_{1}$ & 0.018 & 0.024 & $0.000^{* * *}$ \\
\hline$F R_{2}$ & 2.097 & 2.312 & 0.283 \\
\hline$F V$ & 1.512 & 1.358 & $0.000^{* * *}$ \\
\hline$D E B T$ & 0.593 & 0.559 & $0.021^{* *}$ \\
\hline$F D C$ & 0.489 & 0.465 & $0.087^{*}$ \\
\hline$I N C$ & 9.498 & 7.893 & $0.014^{* *}$ \\
\hline$S I Z E$ & 6.547 & 6.399 & $0.004^{* *}$ \\
\hline$A F C F$ & 1.497 & 0.826 & $0.001^{* *}$ \\
\hline$R O A$ & 0.058 & 0.017 & $0.027^{* *}$ \\
\hline$D I Q$ & 1.399 & 1.535 & 0.211 \\
\hline$T A X$ & 0.281 & 0.227 & $0.001^{* *}$ \\
\hline$M N G R L$ & 0.279 & 0.251 & 0.330 \\
\hline$F S$ & 53.290 & 51.398 & 0.194 \\
\hline
\end{tabular}

\section{Panel B: Malaysian Firms}

\begin{tabular}{l|c|c|c}
\hline \multicolumn{1}{c|}{ Variable } & Users (1119) & Non-Users(627) & Tests for Differences \\
\hline$F R_{1}$ & 0.110 & 0.186 & $0.000^{* * *}$ \\
\hline$F R_{2}$ & 5.643 & 5.270 & 0.936 \\
\hline$F V$ & 1.259 & 1.847 & 0.197 \\
\hline$D E B T$ & 0.434 & 0.371 & $0.000^{* * *}$ \\
\hline$F D C$ & 0.325 & 0.333 & 0.669 \\
\hline$I N C$ & 19.306 & 24.153 & 0.829 \\
\hline$S I Z E$ & 5.640 & 5.419 & $0.000^{* * *}$ \\
\hline$A G C F$ & 1.421 & 1.299 & 0.269 \\
\hline$R O A$ & 0.050 & 0.048 & 0.393 \\
\hline$L I Q$ & 2.212 & 3.928 & $0.000^{* * *}$ \\
\hline$D P$ & 0.364 & 0.187 & 0.466 \\
\hline$T A X$ & 0.750 & 0.668 & $0.000^{* * *}$ \\
\hline$M N G R L$ & 11.635 & 12.481 & 0.422 \\
\hline$F S$ & 2.571 & 2.125 & $0.000^{* * *}$ \\
\hline$D V R S F$ & 0.618 & 0.501 & $0.000^{* * *}$ \\
\hline
\end{tabular}

Note: $F R_{1}$ depicts variability in operating cash flows and $\mathrm{FR}_{2}$ is measured by variability in earnings per share. Asterisks $(* * *, * *$ and $*$ ) denote significance level at $1 \%, 5 \%$ and $10 \%$ level, respectively.

Source: authors' own 
A non-parametric univariate test is applied in order to test whether a significant difference exists between users and non-users of derivatives with respect to firm specific characteristics. Panel A reports the univariate analysis of Pakistani firms and shows that the user has lesser cash flow variability and earnings per share compared to non-users, while a significant difference exists between users and non-users with respect to volatility in operating cash flows. Users have a significantly higher firm's value, indicating the risk management use of corporate derivatives in Pakistani firms. Users are significantly different from non-users with respect to all variables except liquidity, tax losses and managerial ownership. The univariate results of Malaysian firms are reported in Panel B of Table 3, illustrating that users have significantly lower and higher unpredictability in operating cash flow and earnings per share respectively. However, derivative users have lower firm value reflecting the manipulative or speculative use of derivative instruments. Moreover, users are found to be significantly different from non-users with respect to debt, size, liquidity, tax convexity and exchange rate exposure.

Column 1 in Table 4 reports the estimated results of determinants of derivative usage by Pakistani firms. The findings show that the use of derivative instruments, both FCD and IRD, are significantly influenced by leverage, size, profitability and ER exposure. Estimates demonstrate the significant positive effect of leverage on firm's derivative usage, implying that corporations having higher leverage are more likely to use derivative instruments for risk management purposes in order to avoid financial distress costs and agency costs of debt. Their size illustrates the significant positive impact of derivative usage, consistent with Kim et al. (2006) and Junior (2007). Supporting this, in the developing derivative market, profitability documents the significant positive impact on the use of derivative instruments which implies that highly profitable firms have enough cash in hand to pay high transaction costs, therefore they tend more towards the use of derivative instruments, consistent with Joseph (2000). Supported by risk management literature, corporations with higher foreign sales are more exposed to the ER exposure (Goldberg et al. 1998 and Junior, 2007) due to highly volatile currency movements, thus their chances of using derivative instruments increase. Diversification demonstrates insignificant effect on firm's derivative usage, consistent with the substitution hypotheses. All other variables show the insignificant effect on firm's derivative usage.

Furthermore, the study classifies the sample data on the basis of types of derivative instruments and shows that Pakistani firm's decision to use FCD 
instruments is significantly determined by size, growth opportunities, profitability, liquidity and ER exposure. This indicates that large size and growth oriented firms are using more FCDs for risk management purposes. While Pakistan has a developing derivative market, therefore firms which have higher liquid funds and profitability are more likely to use FCDs. Moreover, firms which have higher foreign sales and geographical diversification are more likely to use FCDs to manage ER exposure. The results in column 3 show that a Pakistani firm's decision to use IRD is significantly determined by debt, size and profitability, implying that the under-developed debt market of Pakistan limits a firm's availability to acquire funds at lower rates and hence they are more likely to use IRDs to minimize the IR rate exposure.

Column 4 illustrates the determinants of derivative usage of Malaysian firms and identifies the interest coverage ratio, size and diversification as significant determinants of derivative usage. The significant negative relationship of derivative usage with an interest coverage ratio implies that firms with lower ability to pay their interest payments tend more towards derivative usage as they are capable of paying transaction costs. Like Pakistan, large sized Malaysian firms are using derivative instruments for managing firm's risk, consistent with economies of scale. The significant positive effect of geographical diversification on firm's derivative usage supports the complementary hypothesis that firms that are more geographically diversified have a higher ER exposure, which increases their chances of derivative usage. Results on the basis of the sub-division of sample data with respect to the types of derivative instruments illustrate that a Malaysian firm's decision to use FCDs is significantly determined by the lower financial distress costs, size, profitability, managerial ownership and foreign sales. This might be because of employing natural risk management techniques by Malaysian firms for managing their ER exposures. Contrary to this, Malaysian firms are using IRDs in cases of higher debt, interest coverage ratio, size, profitability, tax, foreign sales and diversification. Summarizing the above discussion, the study finds that both Pakistani and Malaysian firms are using derivatives for hedging purposes as such usage reduces agency costs, financial distress costs, the underinvestment problem, liquidity constraints and ER exposure. The study furthermore directly examines whether such usage helps firms in reducing firm's risk and maximizing value or not? 
Table 4

Determinants of Derivative Usage

\begin{tabular}{l|c|c|c|c|c|c}
\hline \multirow{2}{*}{ Variable } & \multicolumn{3}{|c|}{ Pakistan } & \multicolumn{3}{c}{ Malaysia } \\
\cline { 2 - 7 } & Al Firms & FCD & IRD & All Firms & FCD & IRD \\
\hline Constant & $-2.303^{* *}$ & $-3.41^{* * *}$ & $-1.81^{* *}$ & $-3.74^{* * *}$ & $-5.46^{* * *}$ & $-3.41^{* * *}$ \\
\hline$D E B T$ & $1.08^{* *}$ & 0.21 & $1.38^{* *}$ & 0.24 & 0.36 & $0.76^{* *}$ \\
\hline$F D C$ & 0.234 & -0.27 & 0.09 & -0.03 & $0.52^{* * *}$ & -0.08 \\
\hline$I N C$ & 0.007 & 0.01 & 0.01 & $-0.002^{*}$ & $0.01^{*}$ & $-0.0003^{*}$ \\
\hline SIZE & $0.293^{* *}$ & $0.34^{* * *}$ & $0.19^{* *}$ & $0.75^{* * *}$ & $0.57^{* * *}$ & $0.58^{* * *}$ \\
\hline$M K B K$ & 0.021 & $0.05^{*}$ & 0.02 & -0.03 & -0.0002 & $-0.04^{*}$ \\
\hline$A G C F$ & 0.02 & 0.01 & -0.01 & 0 & -0.01 & 0.003 \\
\hline$R O A$ & $3.03^{* *}$ & $4.09^{* * *}$ & $2.94^{* *}$ & 0.68 & $3.63^{* * *}$ & $-1.70^{* * *}$ \\
\hline LIQ & -0.07 & $0.41^{* * *}$ & -0.07 & 0.003 & -0.04 & 0.01 \\
\hline$D P$ & 0.185 & 0.12 & 0.16 & 0.02 & 0.04 & 0.01 \\
\hline$T A X$ & 0.03 & 0.21 & -0.05 & 0.152 & -0.21 & $0.36^{* *}$ \\
\hline$M N G R L$ & 0.001 & 0.002 & 0.0002 & 0.044 & $0.02^{* * *}$ & -0.002 \\
\hline$F S$ & $0.074^{* *}$ & $0.16^{* * *}$ & 0.04 & -0.002 & $0.26^{* * *}$ & $-0.06^{* *}$ \\
\hline DVRSF & 0.913 & $0.011^{*}$ & 0.01 & $0.352^{* *}$ & 0.17 & $0.29^{* *}$ \\
\hline Log Likelihood & -583.92 & -591.95 & -620.60 & -947.68 & -807.46 & -1023.84 \\
\hline
\end{tabular}

Note: Asterisks $(* * *, * *$ and $*$ ) denote significance level at $1 \%, 5 \%$ and $10 \%$ level, respectively.

Source: authors' own

Table 5 presents the empirical findings regarding the effect of derivative usage on firm's risk of Pakistani and Malaysian firms, along with the other control variables. The analysis demonstrates the significant negative relationship of derivative usage with firm's risk, indicating the derivatives are used by Pakistani firms for minimizing their risk in column 1. Regarding the control variables, the study finds financial distress costs, size, tax losses and diversification as significant determinants of a firm's risk. The significant negative relationship of geographical diversification with risk of Pakistani firms shows that operational hedging helps in minimizing firm's risk, although the reduction in risk is made higher by financial hedging. Column 2 estimates the influence of derivative usage on firm's unpredictability in earnings per share and shows the insignificant relationship of derivative usage with firm's risk as higher transaction costs enhance unpredictability in firm's earnings. The results on the basis of the sample classification with respect to the types of derivative instruments support earlier findings that the use of derivatives, both FCD and IRD, 
significantly minimizes firms operating cash flow variability. Although the reduction in operating cash flow variability is higher in firms using FCDs in contrast to IRDs, and this might be because of high volatility in ERs which gives firms an incentive to use FCDs for risk management. However, firms volatility in earnings per share is irrelevant of the firm's decision to use derivatives, both FCDs and IRDs.

The results in column 7 show the significant negative effect of the derivative usage on firm's risk with respect to the volatility in operating cash flows. This implies that Malaysian non-financial firms are using derivative instruments for managing firm's risk, although the magnitude of risk reduction is higher in comparison to Pakistani firms. This indicates that as Malaysian firms are more exposed to risks due to their involvement in international trade activities, therefore the magnitude of their risk reduction benefits is higher in contrast to Pakistani firms, in line with Kim et al. (2006). Regarding control variables, the study identifies leverage, financial distress costs, profitability and foreign sales as significant determinants of firm's volatility in operating cash flows. The insignificant positive effect of diversification on firm's risk supports the complementary hypothesis by Kim et al. (2006), that financial derivatives help in mitigating firm's risk in conjunction with an operational hedging technique. The results regarding the effect of derivative usage on firm's risk, measured by the volatility in earnings per share in column 4, imply that Malaysian firms are using derivatives to lessen volatility in earnings per share contrary to the findings of Bartram et al. (2011). However, derivative usage decreases volatility in firm's operating cash flow to a greater extent compared to the volatility in earnings per share. Regarding other control variables, the study illustrates leverage, size and diversification as significant determinants of firm's unpredictability in earnings per share. The significant positive effect of diversification on firm's volatility in earning per share implies that operational hedging enhances firm's volatility in the ER. On the whole, the models are significant at $1 \%$, having no auto correlation problem as reflected by the Durbin-Watson test values and possess good adjusted $\mathrm{R}$ squares. Similarly to Pakistani firms, the findings show that Malaysian firms have higher risk reduction incentives from FCD usage in contrast to IRDs and this might result from their high risk exposure, as Malaysian firms are more likely to be involved in geographical diversification. In addition, the developing debt market of Malaysia enables firms to acquire loans at lower rates, thus minimizing the risk reduction incentives of derivative usage, while both FCD and IRD usage fail to demonstrate any significant role in minimizing volatility of firm's earnings per share. 


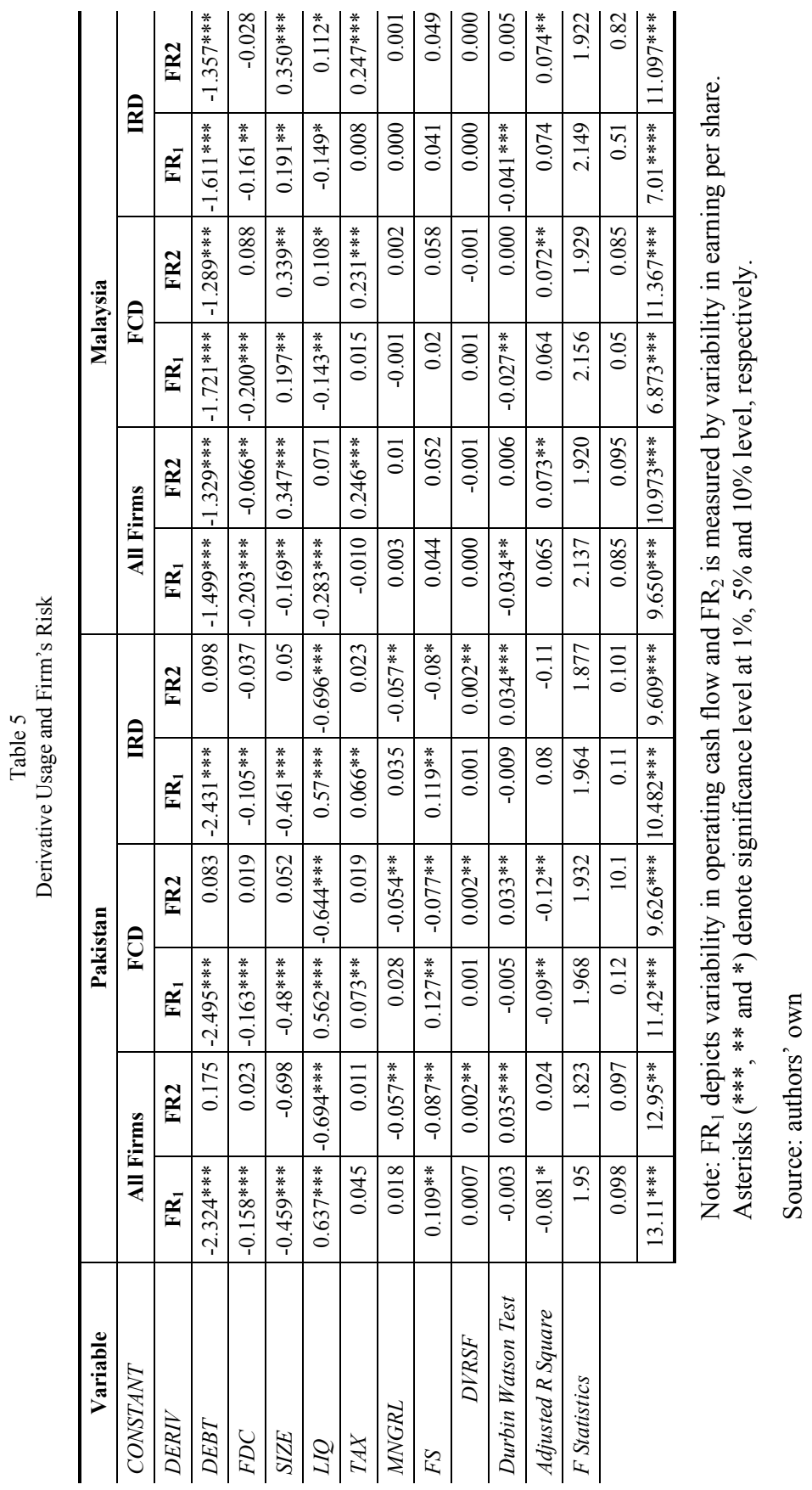


Table 6 shows the effect of derivative usage on the firm's value of Pakistani and Malaysian non-financial firms as risk management theorists state that derivative usage helps in enhancing firm value by minimizing firm's risk. The study found a significant positive relationship between derivative usage and firm's value of Pakistani corporations in column 1, confirming previous findings that Pakistani non-financial firms use derivatives for risk management purposes, consistent with Allayannis and Weston (2001). Regarding firm specific factors, the results illustrate the significant positive effect of leverage with firm value, supported by trade-off theory. However, firms which are stronger to pay their interest payments also have higher firm value, in line with Allayannis et al. (2001). Columns 2 and 3 show empirical findings regarding the value relevance of derivative usage and prove the risk management use of FCD and IRD instruments in Pakistani non-financial firms. Consistent with the earlier findings, the value relevance of FCD usage is higher in contrast to IRDs in Pakistani firms.

Table 6

Derivative Usage and Firm Value

\begin{tabular}{l|r|r|r|r|r|r}
\hline & \multicolumn{3}{|c|}{ Pakistan } & \multicolumn{3}{c}{ Malaysia } \\
\hline Variable & \multicolumn{1}{|c|}{ All Firms } & \multicolumn{1}{c|}{ FCD } & \multicolumn{1}{c|}{ IRD } & \multicolumn{1}{c}{ All Firms } & \multicolumn{1}{c}{ FCD } & \multicolumn{1}{c}{ IRD } \\
\hline Constant & -0.134 & $-0.499^{* * *}$ & \multicolumn{1}{c|}{$-0.516^{* * *}$} & $0.252^{* *}$ & $0.271^{* * *}$ & $0.251^{* *}$ \\
\hline DERIV & $0.07^{* * *}$ & $0.065^{* *}$ & $0.046^{* *}$ & -0.006 & $0.043^{* *}$ & $-0.024^{*}$ \\
\hline DEBT & $0.214^{* * *}$ & $0.469^{* * *}$ & $0.456^{* * *}$ & $0.407^{* * *}$ & $0.397^{* * *}$ & $0.408^{* * *}$ \\
\hline FDC & -0.176 & -0.047 & -0.05 & $0.51^{* * *}$ & $0.145^{* * *}$ & $0.154^{* * *}$ \\
\hline SIZE & 0.005 & 0.011 & 0.013 & $-0.090^{* * *}$ & $-0.095^{* * *}$ & $-0.087^{* * *}$ \\
\hline ROA & $0.063^{*}$ & $0.043^{* *}$ & $0.043^{*}$ & $0.984^{* * *}$ & $0.936^{* * *}$ & $0.976^{* * *}$ \\
\hline DP & $0.05^{* *}$ & $0.037^{* *}$ & $0.037^{* *}$ & 0.0007 & 0.001 & 0.001 \\
\hline TAX & $0.037^{* *}$ & $0.046^{* *}$ & $0.048^{* *}$ & 0.002 & 0.009 & 0.004 \\
\hline MNGRL & $0.001^{* *}$ & $0.0001^{* * *}$ & $0.001^{* * *}$ & $-0.002^{* * *}$ & $-0.003^{* * *}$ & $-0.002^{* * *}$ \\
\hline FS & $-0.013^{* * *}$ & $-0.011^{* * *}$ & $-0.009^{* * *}$ & 0.0004 & -0.003 & 0.000 \\
\hline DVRSF & 0.016 & 0.019 & 0.017 & $-0.047^{* *}$ & $-0.043^{* *}$ & $-0.046^{* *}$ \\
\hline Durbin & & & & & & \\
Watson test & 2.13 & 1.785 & 1.788 & 1.98 & 2.029 & 2.025 \\
\hline Adjusted R & & & & & & \\
Square & 0.106 & 0.195 & 0.188 & 0.213 & 0.213 & 0.212 \\
\hline F Statistics & $12.8^{* * *}$ & $20.99^{* * *}$ & $20.21^{* * *}$ & $33.70^{* * *}$ & $30.968^{* * *}$ & $31.322^{* * *}$ \\
\hline
\end{tabular}

Note: Asterisks $(* * *, * *$ and $*$ ) denote significance level at $1 \%, 5 \%$ and $10 \%$ level, respectively.

Source: authors' own 
In the case of Malaysia the use of derivative instruments fails to prove any significant influence on firm's value, indicating that as Malaysian firms are more operationally hedged and geographically diversified, therefore the value relevance of derivative usage as a risk management instrument is limited in Malaysia. Moreover, Malaysia has a relatively developed capital market which facilitates firms in acquiring external financing at lower rates, thus minimizing the likelihood of employing derivatives for risk management. Regarding control variables, financial distress costs, size, profitability, managerial ownership and geographical diversification are identified as a significant determinants of Malaysian firm's value. The results on the basis of types of derivative instruments show that the use of FCD gives value premium to Malaysian firms in contrast to IRD, in line with the previous findings. This may be because of high ER exposure in Malaysian firms due to their greater involvement in international trade activities, hence valued positively by investors. In the case of IRD usage, as mentioned previously, the developed debt market of Malaysia limits the value relevance of IRD instruments.

Furthermore, in order to provide robustness to earlier findings, the study re-examines the determinants of derivative usage, both FCD and IRD, by using notional value as a dependent variable rather than dummy variable. The Tobit model is used as a large number of observations are censored to zero. Unreported regression results are similar, that both FCD and IRD help in minimizing firm's risk in cases of higher financial distress costs, liquidity constraints and ER exposure. Furthermore, in order to avoid time and year effect while regressing the effect of derivative usage on firm's risk and value, the study uses a fixed/random effect approach to re-examine the risk reduction and value increasing effects of derivative usage. Undocumented regression results show that risk minimizing and value increasing effects of derivative usage is limited in Malaysian firms, consistent with the previous results. This indicates that the involvement of firms in natural risk management activities and the ability of firms to acquire loans at lower rates due to the developed debt market minimizes the risk management role of derivatives in Malaysian firms, in contrast to Pakistan. In addition, in order to test endogeneity, the study uses a simultaneous equation model and reexamines the relationship between derivative usage and firm value, in line with Fauver and Naranjo (2010). Hence the study simultaneously analyses the OLS model for firm's value and the Logit model for derivative usage in the first stage by using liquidity as a potential instrumental variable (Lookman, 2004). The predicted values of firm's value and derivative usage 
are then used in the second stage and unreported results show consistent findings in the case of Pakistan that investors positively value firms using derivatives for hedging purposes. While in the case of Malaysia, the findings illustrate no significant relationship between derivative usage and firm value, indicating that Malaysian firm's decision to use derivatives are driven by firm specific factors other than the firm's value.

\section{CONCLUSION}

The paper employs data from 165 and 266 non-financial firms operating in Pakistan and Malaysia, respectively, to comparatively examine the risk management practices by empirically analyzing the determinants of derivative usage and its respective impact on firm's risk and value. By using dummy variables as a dependent variable, the study finds that in contrast to Malaysia, Pakistani firms are using derivative instruments more for risk management as financial distress costs, under-investment problem and liquidity are identified as significant determinants of derivative usage. For a better understanding, the study further analyses the effect of derivative usage on firm's risk and value.

Empirical findings imply that firms can minimize their risk by using derivative instruments for risk management though the usage of derivatives minimizes firm's risk and enhances firm's value, but despite the significant risk reduction effects of derivative usage in both Pakistan and Malaysia, derivative usage does not maximize firm's value of Malaysian firms significantly. This suggests that firms are using operating hedging in parallel with financial hedging which limit the value relevance of derivative usage. In addition to this the findings suggest that countries with a developed capital market have fewer benefits while employing derivative instruments, as they have easy access to external financing at lower rates. Future research could be possible by comparatively analyzing the Pakistani firms with firms in countries where derivative markets are developed.

\section{REFERENCES}

Afza, T., Alam, A., The Determinants of Extent of Financial Derivative Usage, "African Journal of Business Management”, 5(20), pp. 8831-8836, 2011.

Afza, T., Alam, A., Corporate Derivatives and FX Risk Management: A Case Study of Nonfinancial Firms of Pakistan, "Journal of Risk Finance”, 12(5), pp. 409-420, 2011.

Afza, T., Alam, A., Determinants of Corporate Hedging Police: A Case of FX and Interest Rate Derivative Usage, “African Journal of Business Management”, 5(14), pp. 5792-5797, 2011. 
Allayannis, G., Rountree, B., Weston, J., Earnings Volatility, Cash Flow Volatility and Firm Value, American Accounting Association, Annual Meeting. 2006.

Allayannis, G., Weston, J. P., The Use of Foreign Currency Derivatives and Firm Market Value, "Review of Financial Studies", 14(1), pp. 243-276, 2001.

Ameer, R., Value-relevance of Foreign Exchange and Interest-rate Derivatives Disclosure. The Case of Malaysian Firms, "Journal of Risk Finance", 10(1), pp. 78-90, 2009.

Ameer, R., Determinants of Corporate Hedging Practices in Malaysia, "International Business Research", 3(2), pp. 120-130, 2010.

Aysun, U., Guldi, M., Derivatives Market Activity in Emerging Markets and Exchange Rate Exposure. "Emerging Market Finance and Trade", 47(6), pp. 46-67, 2011.

Bartram, S. M, Brown, G. W, Conrad, J., The Effects of Derivatives on Firm Risk and Value, "Journal of Financial and Quantitative Analysis", 46(4), pp. 967-999, 2011.

Black, F., Scholes, M., The Pricing of Options and Corporate Liabilities. "Journal of Political Economics", 81(3), pp. 637-654, 1973.

Borokhovich, K. A, Brunarski, K. R., Crutchley, C. E., Simkins, B. J., Board Composition and Corporate Use of Interest Rate Derivatives, "Journal of Financial Research", 27(2), pp. 199-216, 2004.

Carter, D. A., Rogers, D. A., Simkins, B. J., Hedging and Value in the U.S. Airline Industry, "Journal of Applied Corporate Finance", 18(4), pp. 21-33, 2006.

Chiang, Y. C., Lin, H. J., Foreign Exchange Exposure, Financial and Operational Hedging Strategies of Taiwan Firms. "Investment Management and Financial Innovation", 4(3), pp. 95-105, 2007.

Clark, E., Judge, A., Mefteh, S., Corporate Hedging with Foreign Currency Derivatives and Firm Value. Unpublished paper. Available at https://www.researchgate.net/ publication/ 228846851, 2006.

Clark, E., Mefteh, S., Foreign Currency Derivatives Use, Firm Value and the Effect of the Exposure Profile: Evidence from France. "International Journal of Business" 15(2), pp. 183, 2010.

Dan, C., Gu, H., Xu, K., The Impact of Hedging on Stock Return and Firm Value: New Evidence from Canadian Oil and Gas Companies. Unpublished paper. Available at https://www.researchgate.net/publication/4861258, 2005.

Kadir, D. A., Minister of Culture and Tourism Malaysia Stated during His Visit to Pakistan, "Dawn”, (Karachi), 18 July 2003.

Davies, D., Eckberg, C., Marshall, A., The Determinants of Norwegian Exporters' Foreign Exchange Risk Management. "European Journal of Finance", 12(3), pp. 217-240, 2006.

El-Mersy, A. A., Derivatives Use and Risk Management Practices by UK Non-financial Companies. "Managerial Finance", 32(2), pp. 137-159, 2006.

Fabian, J., Gregg 'Basically' Has an Agreement on Derivatives Language. Retrieved from https://thehill.com/blogs/blog-briefing-room/news/93217-gregg-basically-has-agreementon-derivatives-language, 2010.

Faseruk, A., Mishra, D. R., An Examination of US Dollar Risk Management by Canadian Non-financial Firms, "Management Research News", 31(8), pp. 570-582, 2008. 
Fauver, L., Naranjo, A., Derivative Usage and Firm Value: The Influence of Agency Costs and Monitoring Problems, "Journal of Corporate Finance", 16, pp. 719-735, 2010.

Fazillah, M., Hui, T. S., Azizan, N. A., The Relationship between Hedging Through Forwards, Futures \& Swaps and Corporate Capital Structure in Malaysia. Second Singapore International Conference on Finance 2008. Available at SSRN: https://ssrn.com/abstract=1083922.

Froot, K. A., Scharfstein, D. S., Stein, J. C., Risk Management: Coordinating Corporate Investment and Financing Policies, "Journal of Finance”, 48(5), pp. 1629-1658, 1993.

Gay, G. D, Lin, C. M, Smith, S. D., Corporate Derivatives Use and Cost of Equity, "Journal of Banking and Finance”, 35(6), pp. 1491-1506. 2011.

Gomez-Gonzalez, J. E., Rincon, C. L., Rodriguez, K. J. L., Does the Use of Foreign Currency Derivatives Affect Colombian Firm's Market Value?, Banco Central de Colombia "Borradores de Economía", p. 562, 2009.

Graham, J. R., Rogers, D., Do Firms Hedge in Response to Tax Incentives?, "Journal of Finance", 57, pp. 815-839, 2002.

Hagelin, N., Why Firms Hedge with Currency Derivatives: An Examination of Transaction and Translation Exposure, "Applied Financial Economics”, 13(1), pp. 55-69, 2003.

Haushalter, G. D., Financing Policy, Basis Risk, and Corporate Hedging: Evidence from Oil and Gas Producers, "Journal of Finance", 55(1), pp. 107-152. 2000.

Hentschel, L., Kothari, S. P., Are Corporations Reducing or Taking Risks with Derivatives?, "Journal of Financial and Quantitative Analysis, 36(1), pp. 93-118, 2001.

Hohensee, M., Lee, K., A Survey on Hedging Markets in Asia: A Description of Asian Derivatives Markets from a Practical Perspective. Asian Bond Markets: Issues and Prospects, BIS Papers, 30, pp. 261-281, 2006.

Horng, Y.-S., Wei, P. An Empirical Study of Derivatives Use in the REIT Industry, "Real Estate Economics", 27(3), pp. 561-586, 1999.

Hsu, S., Ko, P.-S., Wu, C.-C., Cheng, S.-R., Chen, Y.-S., Hedging with Derivatives by Taiwanese Listed Non-financial Companies, "International Journal of Electronic Finance", 3(3), pp. 211-234, 2009.

Hu, C., Wang, P., The Determinants of Foreign Currency Hedging - Evidence from HongKong Non-financial Firms, “Asia-Pacific Financial Markets”, 12(1), pp. 91-107, 2005.

Jensen, M. C., Meckling, W. H., Theory of the Firm: Managerial Behavior, Agency Costs and Capital Structure, "Journal of Financial Economics", 3(4), pp. 305-360, 1976.

Jin, J., Jorion, P., Firm Value and Hedging: Evidence from US Oil and Gas Producers. "Journal of Finance" 61(2), pp. 893-919, 2006.

Jorge, M. J., Augusto, M. A., Financial Risk Exposures and Risk Management: Evidence from European Non-financial Firms, "Revista de Administração Mackenzie" 12(5), pp. 65-97, 2011.

Joseph, N. L., The Choice of Hedging Techniques and the Characteristics of UK Industrial Firms, "Journal of Multinational and Financial Management", 10(2), pp. 161-184, 2000.

Junior, J. L. R., The Use of Currency Derivatives by Brazilian Companies: An Empirical Investigation, "Revista Brasileria de Finanças", 5(2), pp. 205-232, 2007. 
Kapitsinas, S., Derivatives Usage in Risk Management by Non-financial Firms: Evidence from Greece, MPRA Paper No. 10945, http://mpra.ub.uni-muenchen.de/10945/, 2008.

Khediri, K. B., Do Investors Really Value Derivatives Use? Empirical Evidence from France, "Journal of Risk Finance", 11(1), pp. 62-74, 2010.

Kim, Y. S., Mathur, I., Nam, J., Is Operational Hedging a Substitute for or a Complement to Financial Hedging?, "Journal of Corporate Finance”, 12(4), pp. 834-853, 2006.

Lookman, A., Does Hedging Increase Firm Value? Evidence from Oil and Gas Producing Firms, EFA 2004 Maastricht Meetings Paper No. 5174. 2004.

Modigliani, F., Miller, M. H., Are Corporations Reducing or Taking Risks with Derivatives?, "Journal of Financial and Quantitative Analysis", 36(01), pp. 93-118. 2001.

Mohammed, A., Kayani, J., Rafiq, K., An Investigation into the Global Financial Crises Factors and a Snap Shot of Their Impact on Different Segments of Economy in a Developing Country: A Case of Pakistan, "International Journal of Academic Research in Business and Social Sciences”, 2(9), pp. 384-391, 2012.

Muller, A., Verschoor, W. F. C., Asian Foreign Exchange Risk Exposure, "Journal of the Japanese and International Economies", 21(1), pp. 16-37, 2007.

Myers, S., Determinants of Corporate Borrowing, "Journal of Financial Economics", 5(2), pp. 147-175, 1977.

Naito, J., Laux, J., Derivatives Usage: Value-Adding or Destroying?, “Journal of Business and Economics Research", 9(11), pp. 41-50, 2011.

Nguyen, H., Faff, R. W., Are Firms Hedging or Speculating? The Relationship between Financial Derivatives and Firm Risk, "Applied Financial Economics”, 20(10), pp. 827843, 2010a.

Nguyen, H., Faff, R. W., Does the Type of Derivative Instruments Used by Companies Impact Firm Value?, “Applied Economics Letter”, 17(7), pp. 681-683, 2010 b.

Nguyen, H., Faff, R. W., Further Evidence on the Corporate Use of Derivatives in Australia: The Case of Foreign Currency and Interest Rate Instruments, "Australian Journal of Management", 28(3), pp. 307-318, 2003.

Nguyen, H., Faff, R. W., On the Determinants of Derivative Usage by Australian Companies, "Australian Journal of Management", 27(1), pp. 1-24, 2002.

Nguyen, H. V., Why do Non-Financial Firms Select One Type of Derivatives Over Others, "Journal of Applied Business and Economics", 12(3), pp. 91-109, 2011.

Paligorova, T., Staskow, R., The Use of Financial Derivatives by Canadian Firms, "Bank of Canada Review", pp. 47-54, 2014.

Paracha, S. A., Manzoor, M. R., Economic Evaluation of Pak-Malaysia Free trade agreement, Pakistan Institute of Trade and Development. 2015.

Pramborg, B., Derivatives Hedging, Geographical Diversification, and Firm Market Value, "Journal of Multinational Financial Management", 14(2), pp. 117-133, 2004.

Reynolds, M. P., Bhabra, G. S., Boyle, G. W., Cash Flow, Investment and Derivative Use: An Empirical Analysis of New Zealand Listed Companies. Unpublished paper. Available at: https://ssrn.com/abstract=1030154, 2007.

Schiozer, R. F., Saito, R., The Determinants of Currency Risk Management in Latin American Non-financial Firms, "Emerging Markets of Finance and Trade", 45(1), pp. 49-71, 2009. 
Shamsher, M., Taufiq, H. Asian Derivative Market: Research Issues. "International Journal of Banking and Finance", 5(1), pp. 1-25, 2007.

Singh, A. Upneja, A., The Determinants of the Decision to Use Financial Derivatives in the Lodging Industry, "Journal of Hospitality and Tourism Research", 32(4), pp. 423-447, 2008.

Smith, C. W., Stulz, R. M., The Determinants of Firm Are Hedging Policies, "Journal of Financial and Quantitative Analysis", 20(4), pp. 391-405, 1985.

Stulz, R. M., Optimal Hedging Policies, "Journal of Financial and Quantitative Analysis", 19(2), pp. 127-140, 1984.

Tufano, P., Who Manages Risk? An Empirical Examination of Risk Management Practices in the Gold Mining Industry, "Journal of Finance", 51(4), pp. 1097-1137, 1996.

Received: April 2015, revised: February 2016 